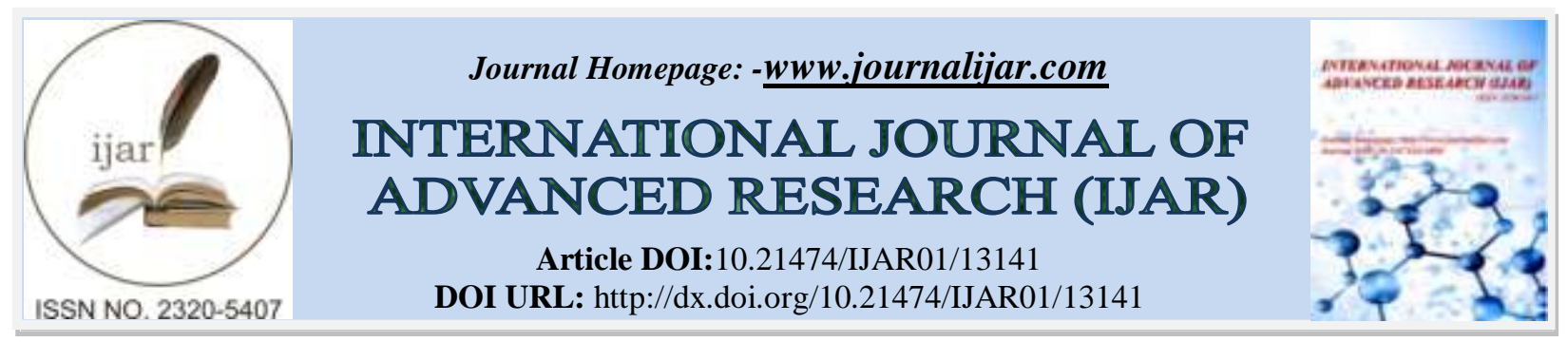

RESEARCH ARTICLE

\title{
RECOGNISING SUSTAINABILITY THROUGH THE CORPORATE REPORTS - A REVIEW OF DEVELOPMENT OF DISCLOSURES IN INDIA
}

\section{Mrs. Priyanka Nayak ${ }^{1}$ and Dr. Narayan Kayarkatte ${ }^{2}$}

1. Current position: Full- time Research Scholar, College of Management and Commerce, Srinivas University, Mangalore. Qualification: Masters in Commerce, $(\mathrm{PhD})$

2. Current Position: Research Professor, Srinivas University Mangalore. Qualification: PhD, MBA (Finance/ HR), MA (Economics), CAIIB, LLB (Labour law and Insurance).

\section{Manuscript Info}

Manuscript History

Received: 10 May 2021

Final Accepted: 14 June 2021

Published: July 2021

Key words:-

Sustainability Reporting, GRI,

Environment reporting, CSR,

Governance disclosure

\begin{abstract}
Purpose: The stride of Sustainability has led to a new form of reporting called Sustainability Reporting. This form of reporting is being widely accepted and has recently surged amongst Indian corporates and researchers. This paper tries studying the evolution of Sustainability Reporting and its development In Indian context. It also attempts to identify the gaps in the available literature, for further research in this area.

Design/Methodology: Using the literature published between 2011 and 2020 review is conducted in various aspects of Sustainability Reporting in India.

Findings: As Sustainability Reporting became popular in India only two decades back, there are several gaps in the study in this area, leading to abundant dimensions for future research. The role of Policy makers, Regulators and Academicians in development of best practices in reporting also is highlighted.

Practical implication: This study shall give a historical perspective of Sustainability Reporting in India and help researchers focus their study on critical areas that need to be researched.

Originality/Value: Sustainability Reporting has drawn a large number of attentions amongst the financial stakeholders. There are several research/review being undertaken in this field. However, a review of the development of studies of Sustainability Reporting in India is one of its kinds. No previous research was found which systematically incorporates evolution and development of Sustainability Reporting in Indian context.
\end{abstract}

Copy Right, IJAR, 2021,. All rights reserved.

\section{Introduction:-}

Sustainability has evolved as buzzword in global economy. A common man understands sustainability as something that we do to protect our environment, our resources for future generations. However, over the years, sustainability has excelled in its scope. It now covers anything and everything done towards the betterment of the People, Planet and Profit. Traditionally, sustainability activities were done while disregarding the accountability. Responsibility becomes ineffective if unbacked by accountability. These gaps lead to Sustainability Reporting. It emerged some 
five decades ago with the environmental reporting and disclosures. Backed by global and international compacts and national policies Sustainability Reporting has emerged as a most widely accepted domain across the globe. It began as a voluntary initiative of the corporates to disclose their efforts towards society, environment, labour and stakeholders. With the emergence of several guidelines and frameworks sustainability reports seem to set a trend in the $21^{\text {st }}$ century corporate reporting.

Over the years, different names have emerged for Sustainability Reporting such as Sustainability Accounting, Triple Bottom Line Reporting, ESG Reporting, Social and Environmental Accounting, Non-Financial Disclosure, Integrated Accounting. Business Responsibility Reporting, Green Accounting, Corporate Citizenship. Though these terms are often used interchangeably, scope of these terms may change with the situations. For e.g. Integrated Reporting means report generated by combining the financial and sustainability reports, (Stolowy\&Paugam, 2018) and CSR disclosure can be something related to social works undertaken by the corporations. Sustainability Reporting has become a researcher's agenda. There have been several studies in various dimensions of Sustainability Reporting.

\section{Objectives of the study:-}

1)To understand the emergence and evolution of Sustainability Reporting.

2)To study the role of sustainability reporting in value addition/performance of the firms.

3)To evaluate various studies on different dimensions of sustainability.

4)To analyse the development and current stage of Sustainability Reporting in India and the gaps in the study.

5)To identify the most researched areas of Sustainability Reporting in India.

\section{Methodology:-}

This paper reviews the existing available literature in the years 2011 to 2020. Various research papers, review papers and case studies published in peer-reviewed Indian and international journals are collected using Google Scholar search engine. The key word searched is "Sustainability Reporting in India".

For understanding of the evolution and theories, cross reference and a specific keyword search was also adopted.

Few other published sources such as books, thesis, websites and corporate reports have also been referred to understand the contents and concepts.

Studies in Sustainability Reporting according to Google scholar

\begin{tabular}{|l|l|}
\hline $2011-2020$ & 110 publication \\
\hline $2001-2010$ & 4 \\
\hline Before 2000 & No studies \\
\hline
\end{tabular}

Of these, only 65 papers were considered for this review, tending to its relevance to the topic and information needed.

\section{Evolution of Sustainability Reporting}

The term sustainability was coined late back in the 17th century by a German forester, but it gained popularity only around the 1980s, at the time when environmental depletion and its concern started raising. Scoones, (2007) says that the term sustainability alone cannot be described fully; it is paired with many words like sustainable development, sustainable cities, sustainable building, and sustainable livelihood and so on. One such paired word is corporate sustainability; this has been highly researched word in the past five years. There are various dimensions of corporate sustainability Meuer, Koelbel, \& Hoffmann, (2020), one such dimension is aligning the social, environmental and economic goals with corporate strategies as corporate sustainability.

Sustainability reporting is a kind of value added reporting which consists of information on Economic, Environmental, Social and Governance issues of the organisation, (Nayak and Kayarkatte, 2020). This information can be integrated in the annual reports of the company or reported on the company website or can be published as a standalone report. There are several international principles/frameworks guiding such reporting practices. India has launched National Voluntary Guidelines to encourage corporations to embrace sustainability reporting. Sustainability reports also serve as a tool to corporate public relations as they satisfy the expectation of most of the 
stakeholders. They also encourage corporate to engage in an increasing number of sustainable activities as SRs make organisations more responsible and accountable.

Some anti-environmental incidences during the 1970s and 1980s called for the responsibility of corporates and private sector towards environment. This led to the integration of reporting of financial information with environmental disclosure using CERES (Coalition of Environmentally Responsible Economies Principles), Busco and Sofra (2021). In most developed nations Sustainability Reporting first emerged from environmental reporting. Let us discuss the evolution of Sustainability Reporting. Fig. 1 shows the evolution of Sustainability Reporting over the last five decades.

(Mohanty, 2018) in her article on Sustainability Accounting says that such non-financial reporting makes the organisations accountable and hence enhances trust worthiness. With this the there was a stride in the corporates reporting sustainability, some reported through websites, whilst others through annual reports. In the past decade, most large corporations have created a standalone sustainability reports. Company size, industry sector, political, social, culture, profitability are some factors responsible for the Sustainability disclosures, (Ali, Jedrzej and Zeeshan, 2017).

Figure 1:- Diagram representing the evolution of Sustainability Reporting.

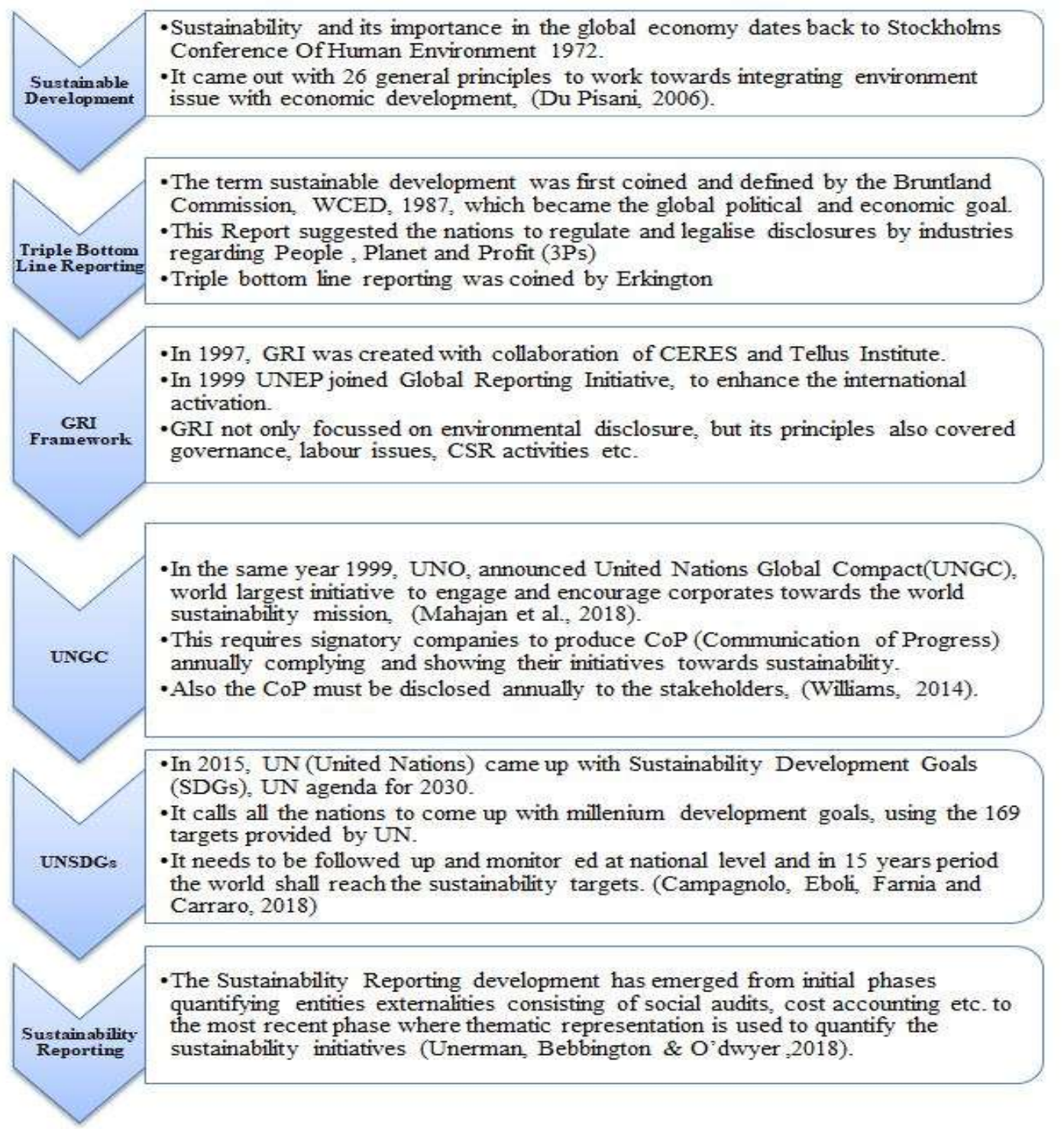




\section{Theoretical background of Sustainability Reporting}

Corporate reporting is based on and is supported by several theories such as Positive Accounting Theory, Signalling Theory, Agency Theory, Political Economic Theory, Stakeholder Theory, Legitimacy Theory and Contingency Theory. Although these theories provide a substantial base for reporting, there is no universal theory on which reporting is based. This depends on the situations, managerial preferences, organisational culture and climate, (Ahmed and M. El-Galfy, 2014). Sustainability Reporting is an emerging concept, but most of the theories backing corporate reporting have already provided a firm base for this reporting dimension. These theories help us understand by firms are opting for Sustainability Reporting. Let us look into some theories

\section{Stakeholder Theory}

Stakeholder theory has considerable importance in Sustainability Reporting. It suggests that business must consider all the constituent groups while conducting business, hence disclosing the impact and profit of the business to all stakeholders is important. Stakeholders both internal and external play as key drivers for reporting sustainability both in developed and developing countries, (Ali, Jedrzej and Mahmood, 2016). The interviews conducted on professional accountants in Ghana reveal that Sustainability Reporting depends on the availability of resources and stakeholders demands. (Ossei et al., 2018). The key contributors of this theory areUlman 1985, Gray 1995, Deegan 2000 .

\section{Legitimacy Theory}

This theory argues that any business does not have direct access to any resources, but must have a licence to use it. The working of the organisation depends on the legitimacy/acceptance of society alone. So protecting this interest is of utmost importance, (Hahn and Kühnen, 2013). In order to anchor the company smoothly, they must report on various aspects related to the use of resources such as Men, Material, Machine and Money. It is a construct for CSR in India, (Jessop, Wilson, Bardecki, and Searcy, 2019). The main researchers of this theory include Dowling and Peffer 1975, Lopez and Rodrigues, 2000, Deegan 2002, Donovan 2002.

\section{Contingency Theory}

Contingencies are uncertainties that affect the working of the organisations. There are both internal and external contingencies. Business need to work towards the internal contingencies that are under the control of the organisation. They should report their initiatives for the external contingencies, (Alves, De Sousa, Kannan and Jabbour, 2017).Some important contributors are, Lawrence And Lorsh, 1967, Schwiekart, 1985, Chapman 1997.

\section{Social Contracts Theory}

The stakeholders' acceptance of organisations value is more important (Deegan, 2014). The economic activities backed by strong profit motives mostly lead us to choose between what is ethical or not. There is quite a difference between what is legal and what is morally acceptable, social contracts theory distinguishes these and Integrative Social Contracts Theory helps us integrate ethics into economic activities. Donaldson, T., \&Dunfee, T. (1995).

Many researchers strongly believe there is a connection between stakeholder theory, legitimacy theory and social contract theory, (Hahn, \&Kühnen, 2013). Every theory supports the existence and development of Sustainability Reporting. There are some other theories supporting the SR like agency theory, institutional theory signalling theory which has not been researched much.

\section{Sustainability Reporting in India - Review on Growth and development}

Societal concerns, environmental protection and ethical considerations have roots embedded in cultural heritage and traditions of India. In modern days it is incorporated in firm foundation in the form of CSR, (Yadav, 2019). Indian environmental and labour laws date back to beginning of the 19th century, (Herremans, 2011). Yadav et al., (2013) said Sustainability Reporting began to trend during the 1980s in developed countries like US. In India, it has taken a surge since the beginning of $21^{\text {st }}$ century, with some large corporation initiating voluntary disclosure of environmental and social aspects of the organisation (Nayak and Kayarkatte, 2020). The main drivers for Indian corporates were international investors' expectations and global reporting standards. In 2012, business responsibility reports were made mandatory for the top 100 listed companies by SEBI. This report must be in line with the National voluntary guidelines on social, environmental and economic responsibilities of business. In 2013 , a major amendment was made to the Companies act 1956, by mandating large Corporates to spend a minimum of $2 \%$ of their net profit towards CSR activities. CSR, which was earlier voluntary contribution was made a mandatory 
requirement, Balachandran et al, (2014) provides an elaborate description on the CSR bill and its various dimensions. Post these several studies conducted on different sectors of Indian industries have shown a significant improvement in reporting sustainability issues, (Goel, 2018). Some of these notable contributions are highlighted in table 1 .

Table 1:- Studies in development of Sustainability Reporting.

\begin{tabular}{|c|c|c|c|c|}
\hline Sl.no. & Contribution & $\begin{array}{l}\text { Research } \\
\text { method }\end{array}$ & $\begin{array}{l}\text { Industry/sample } \\
\text { surveyed }\end{array}$ & Reference \\
\hline 1 & $\begin{array}{l}\text { There was lesser CSR communication, though } \\
\text { they were largely engaged in CSR activities. }\end{array}$ & Content analysis & $\begin{array}{l}100 \text { IT companies of } \\
\text { India }\end{array}$ & $\begin{array}{l}\text { Chaudhary et } \\
\text { al., (2007) }\end{array}$ \\
\hline 2 & $\begin{array}{l}\text { The tourism industry was just reporting the } \\
\text { sustainability measures through its websites, } \\
\text { without any standard format. }\end{array}$ & $\begin{array}{l}\text { Content analysis } \\
\text { of website }\end{array}$ & Tourism & $\begin{array}{l}\text { Herremans, } \\
(2011)\end{array}$ \\
\hline 3 & $\begin{array}{l}\text { Though Indian companies have been working } \\
\text { in the front line for many key environmental } \\
\text { and social issues, the reporting of the same is } \\
\text { not up to the mark. }\end{array}$ & $\begin{array}{l}\text { Literature } \\
\text { review }\end{array}$ & Overall & $\begin{array}{l}\text { Yadav and } \\
\text { Sinha, (2013) }\end{array}$ \\
\hline 4 & $\begin{array}{l}\text { Governance and CSR aspects were the most } \\
\text { reported part. The variables of sustainability } \\
\text { reported varied significantly among the } \\
\text { industry. }\end{array}$ & $\begin{array}{l}\text { Content analysis } \\
\text { Of top } 100 \\
\text { companies }\end{array}$ & Random companies & $\begin{array}{lr}\text { Jose and } \\
\text { Saraf, }(2013)\end{array}$ \\
\hline 5 & $\begin{array}{llll}\text { Most Indian } & \text { companies are } & \text { publishing } \\
\text { sustainability } \\
\text { guidelines. }\end{array}$ & $\begin{array}{l}\text { Analysis of SR, } \\
\text { websites }\end{array}$ & $\begin{array}{l}\text { TCS, Reliance } \\
\text { industries and Wipro }\end{array}$ & $\begin{array}{l}\text { Bhalla and } \\
\text { Bansal, } \\
(2014)\end{array}$ \\
\hline 6 & $\begin{array}{l}\text { Along with GRI guidelines, assuring the } \\
\text { sustainability reports using the ISAE } 3000 \\
\text { standard and AA } 1000 \text { assurance standard and } \\
\text { social auditing is voluntary adopted by the } \\
\text { organisations, }\end{array}$ & $\begin{array}{lr}\text { Analysis } & \text { of } \\
\text { Indian } & \text { reports } \\
\text { through } & \text { GRI } \\
\text { website. } & \end{array}$ & $\begin{array}{l}\text { Indian companies } \\
\text { reporting GRI }\end{array}$ & $\begin{array}{l}\text { Godha and } \\
\text { Jain, (2015) }\end{array}$ \\
\hline 7 & $\begin{array}{l}\text { Sustainability reports of India show that there } \\
\text { is no much differences in the contents of } \\
\text { sustainability reports, but the stakeholders } \\
\text { identified by the companies do differ and } \\
\text { sustainability reports change as per the nature } \\
\text { of the business, }\end{array}$ & $\begin{array}{l}\text { Cross sector } \\
\text { content analysis }\end{array}$ & 36 companies & $\begin{array}{l}\text { Kumar, et al., } \\
\text { (2015) }\end{array}$ \\
\hline 8 & $\begin{array}{l}\text { CSR in India has emerged from just donation } \\
\text { to charity to engaging CSR as a core strategy } \\
\text { of the organisation. The communication of } \\
\text { CSR has a relevant impact on CSR activities } \\
\text { and firm performance. }\end{array}$ & $\begin{array}{l}\text { Literature } \\
\text { survey }\end{array}$ & Overall & Mitra, (2015) \\
\hline 9 & $\begin{array}{l}\text { Most of all corporates abide GRI G3 and G4 } \\
\text { guidelines, but do not consider the industry } \\
\text { characteristics while reporting the same. }\end{array}$ & $\begin{array}{l}\text { Analysis using } \\
\text { GRI Guidelines } \\
\text { framework }\end{array}$ & $\begin{array}{lr}\text { NSE } & \text { listed } \\
\text { companies } & \text { with } \\
\text { large } & \text { market } \\
\text { capitalisation } & \\
\end{array}$ & $\begin{array}{l}\text { Pandya, } \\
\text { (2016) }\end{array}$ \\
\hline 10 & $\begin{array}{l}\text { The stakeholder's perceptions conclude that } \\
\text { Sustainability Reporting is providing integrity } \\
\text { and honesty in the reporting practices. }\end{array}$ & $\begin{array}{l}\text { Perceptions and } \\
\text { attitude analysis }\end{array}$ & $\begin{array}{l}\text { Listed companies, } \\
\text { Cuttack, Odissa. }\end{array}$ & Patra, (2016) \\
\hline
\end{tabular}




\begin{tabular}{|c|c|c|c|c|}
\hline 11 & $\begin{array}{l}\text { A study of Indian companies' disclosure on } \\
\text { sustainability also supports the finding that } \\
\text { energy production industries are reporting } \\
\text { more on sustainability, }\end{array}$ & $\begin{array}{l}\text { Cross sector } \\
\text { comparison of } \\
\text { sustainability } \\
\text { reports }\end{array}$ & $\begin{array}{l}\text { Top } 30 \text { companies } \\
\text { publishing } \\
\text { sustainability reports } \\
\text { as per GRI }\end{array}$ & $\begin{array}{l}\text { Biswas, } \\
(2016)\end{array}$ \\
\hline 12 & $\begin{array}{l}\text { Indian companies reach GRI reporting } \\
\text { standards better than MNCs performing in } \\
\text { India. However, only larger companies in } \\
\text { India report sustainability issues in a } \\
\text { standardised way and follow GRI guidelines. }\end{array}$ & $\begin{array}{ll}\text { Case } & \text { study } \\
\text { approach } & \end{array}$ & $\begin{array}{l}20 \text { largest state- } \\
\text { owned and private } \\
\text { companies in India }\end{array}$ & $\begin{array}{l}\text { Jain and } \\
\text { Winner, } \\
(2016)\end{array}$ \\
\hline 13 & $\begin{array}{l}\text { Sustainability Reporting is standardised, but } \\
\text { at nascent stage in Indian banking system, } \\
\text { hardly six banks were reporting sustainability } \\
\text { adopting global frameworks. }\end{array}$ & Content analysis & $\begin{array}{l}\text { Commercial banks } \\
\text { of India }\end{array}$ & $\begin{array}{l}\text { Kumar and } \\
\text { Prakash, } \\
(2019)\end{array}$ \\
\hline 14 & $\begin{array}{l}\text { In } 2016 \text {, almost } 126 \text { companies in India were } \\
\text { reporting sustainability using GRI guidelines } \\
\text { and there is a significant increase in the } \\
\text { number only after } 2015 \text {. This consists mostly } \\
\text { of large-scale enterprises. Very few small- } \\
\text { scale enterprises were reporting sustainability, } \\
\text { but they show signs of increase. }\end{array}$ & $\begin{array}{l}\text { Growth } \\
\text { analysis }\end{array}$ & 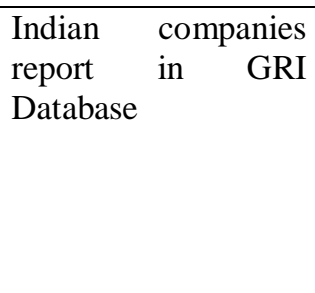 & $\begin{array}{l}\text { Salgoankar, } \\
\text { (2019) }\end{array}$ \\
\hline 15 & $\begin{array}{l}\text { Extensive research of sustainability report } \\
\text { statistically signifies the increasing trend in } \\
\text { sustainability disclosures post SEBI } \\
\text { mandating. It also suggests the adoption of } \\
\text { international guidelines such as UNSDG, GRI } \\
\text { G4. According to } \\
\text { This study highly polluting industries such as } \\
\text { energy, metal and automobiles stand first in } \\
\text { disclosing sustainability, while IT industry } \\
\text { (non-polluting) has been exemplary in } \\
\text { voluntary Sustainability Reporting,. }\end{array}$ & Content analysis & $\begin{array}{l}\text { NSE top } 100 \\
\text { companies' }\end{array}$ & $\begin{array}{l}\text { Kumar, } \\
(2020)\end{array}$ \\
\hline 16 & $\begin{array}{l}\text { The trend in Sustainability Reporting post } \\
\text { regulation and it is evident that Indian firms } \\
\text { are adapting to the global forces and policy } \\
\text { changes voluntarily as they recognise the } \\
\text { importance of Sustainability Reporting. Role } \\
\text { of the state i.e. GOI in Sustainability } \\
\text { Reporting and CSR in appreciated. }\end{array}$ & $\begin{array}{l}\text { Assessing GRI } \\
\text { compliance } \\
\text { using } \\
\text { Sustainability } \\
\text { scores }\end{array}$ & $\begin{array}{l}\text { GRI compliant } \\
\text { companies }\end{array}$ & $\begin{array}{l}\text { Mathivan et } \\
\text { al., (2020) }\end{array}$ \\
\hline 17 & $\begin{array}{l}\text { Moral responsibility, Accountability, and } \\
\text { legal aspects are interrelated. This study } \\
\text { demonstrates accountability through } \\
\text { regulation is important }\end{array}$ & $\begin{array}{l}\text { Framework } \\
\text { building }\end{array}$ & Existing Literature & $\begin{array}{l}\text { Tamveda, } \\
(2020)\end{array}$ \\
\hline
\end{tabular}

This table throws light on three main aspects. They are;

1. Most of the researchers used content analysis as a research method to analyse the development and trends in Sustainability Reporting of India.

2. In India, most large corporations have started to report on Sustainability complying GRI and UNSDGs.

3. Regulations by GOI and SEBI have significantly and positively influenced the reporting and it's standard. 


\section{Studies in the impact of Sustainability Reporting on firm performance/ firm value}

Long back, when sustainability concept was still emerging, there was no considerable impact on profitability [Kenneth et al., 1985] due to CSR disclosures, but the researchers now show a significant impact on profitability. In India, there are a few studies, but even they prove that Sustainability Reporting and firm performance are positively related (refer table 2).

Table 2:- Table depicting Sustainability Reporting and firm performance.

\begin{tabular}{|c|c|c|c|c|}
\hline Sl. No & Outcome & Sample size & Tools used & References \\
\hline 1 & $\begin{array}{l}\text { Corporate sustainability has no significant } \\
\text { impact on Firm's financial performance. }\end{array}$ & $\begin{array}{l}20 \text { companies of } \\
\text { NIFTY-50 }\end{array}$ & $\begin{array}{l}\text { Correlation, } \\
\text { test, F-test. }\end{array}$ & $\begin{array}{l}\text { Agarwal, } \\
(2013)\end{array}$ \\
\hline 2 & $\begin{array}{l}\text { A study conducted on Indian chemical } \\
\text { industries identifies regulations, environmental } \\
\text { crises, economic and demographic conditions } \\
\text { as the major drivers for reporting of } \\
\text { sustainability, but there no significant relation } \\
\text { between firm performance and sustainability } \\
\text { drivers }\end{array}$ & $\begin{array}{l}520 \text { decision- } \\
\text { makers of } \\
\text { chemical } \\
\text { industries in } \\
\text { Gujarat and } \\
\text { Maharashtra }\end{array}$ & $\begin{array}{l}\text { Survey and } \\
\text { interview }\end{array}$ & $\begin{array}{l}\text { Mitra, } \\
\text { Agarwal and } \\
\text { Ghosh, } \\
(2015)\end{array}$ \\
\hline 3 & $\begin{array}{l}\text { BSE CARBONEX index based on S \& P BSE } \\
\text { index is the first index to assess organisational } \\
\text { efforts towards environmental sustainability, }\end{array}$ & $\begin{array}{l}100 \text { Companies } \\
\text { listed on BSE } \\
\text { CARBONEX } \\
\text { index }\end{array}$ & $\begin{array}{l}\text { Panel data } \\
\text { analysis, Paired } \\
\text { t-test, one way } \\
\text { anova }\end{array}$ & Garg, (2016) \\
\hline 4 & $\begin{array}{l}\text { The companies opting for voluntary disclosure } \\
\text { on Environment, Social And Governance } \\
\text { aspect have higher firm value, }\end{array}$ & $\begin{array}{l}\text { BSE } 100 \text { non- } \\
\text { financial } \\
\text { companies }\end{array}$ & $\begin{array}{lr}\begin{array}{l}\text { Panel } \\
\text { analysis }\end{array} & \begin{array}{r}\text { data } \\
\text { andinary } \\
\text { square } \\
\text { regression, } \\
\text { test }\end{array} \\
\end{array}$ & $\begin{array}{l}\text { Charumathi } \\
\text { and Ramesh, } \\
(2020)\end{array}$ \\
\hline 5 & $\begin{array}{l}\text { This study conducted a using Scopus database, } \\
\text { which shows studies on relating firm } \\
\text { performance with sustainability reporting is } \\
\text { conducted in several Asian countries including } \\
\text { India. Furthermore, Indian firms show a } \\
\text { positive firm performance with sustainability } \\
\text { reporting, whereas many other countries show } \\
\text { varied results. }\end{array}$ & Not applicable & $\begin{array}{l}\text { bibliometric } \\
\text { literature review }\end{array}$ & $\begin{array}{l}\text { Jayakumar et } \\
\text { al., (2020) }\end{array}$ \\
\hline 6 & $\begin{array}{l}\text { The relation between Corporate sustainability } \\
\text { performance (CSP) and Corporate financial } \\
\text { performance (CFP) of Indian firms are } \\
\text { insignificant. The main reasons are non- } \\
\text { availability of proper tool for measurement of } \\
\text { the same and Indian firms not receiving } \\
\text { financial benefits of Sustainable investments. }\end{array}$ & $\begin{array}{l}\text { Top } 500 \text { Indian } \\
\text { firms }\end{array}$ & $\begin{array}{l}\text { Correlation } \\
\text { between CSP } \\
\text { and CFP }\end{array}$ & $\begin{array}{l}\text { Jha and } \\
\text { Rangarajan, } \\
(2020)\end{array}$ \\
\hline
\end{tabular}

\section{Dimensions of Sustainability Reporting}

Most of the SR reportsare in four dimensions, i.e Economic, Environmental, Social, Governance and other, while some organisation report only on three dimensions i.e. Environment, Social and Governance (ESG), (Palit, 2018). These are shown in fig. 2 


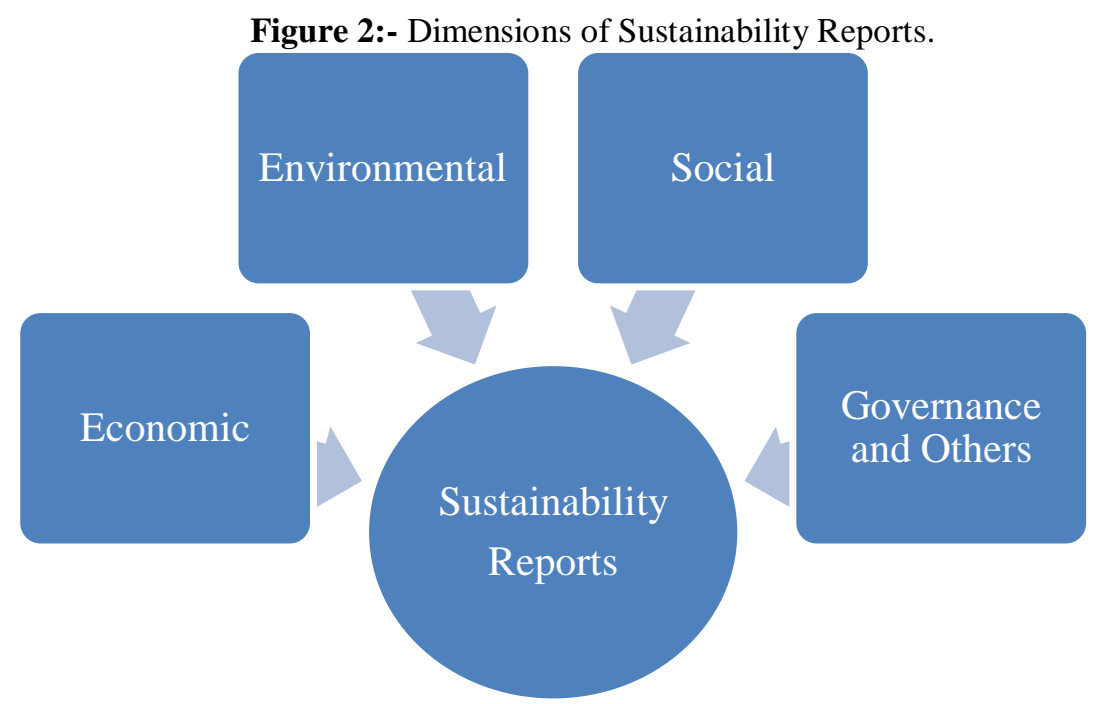

1. Annual reports are particular to the financial achievements and the status of the company. Economic dimension of the sustainability report focus on the financial highlights along with the stakeholder engagement, value chain, effective use of resources, awards and recognition of the company, distribution of profits etc.

2. Environmental aspects like the initiatives taken to control the emission, use of green energy, recycling of waste, treatment of effluents etc. are reported. Environmental reporting is done through the use of various ratios provided under the GRI framework.

3. Corporate social responsibility i.e., organisation commitment towards public welfare and its contribution in the development of the society is reported under the social dimension. It can also include creation of employment opportunities, employee engagement and turnover, educating and training the employees, welfare of employees etc.

4. Governance matters such as board membership, board composition, etc. are the part of annual reports, but the same is highlighted in the sustainability reports focussing more upon the sustainability initiatives by the board, CSR committee and others. Reporting on Governance matters helps the stakeholders understand the commitment of the organisation towards its vision and mission.

The tables following below show some research contributions towards each of these dimensions:

Table 3:- Table depicting studies related economic dimension.

\begin{tabular}{|l|l|l|}
\hline Sl. No. & Contributions & References \\
\hline 1 & $\begin{array}{l}\text { Though economic aspects are disclosed in the annual reports, they are } \\
\text { disclosed differently in the sustainability reports. Economic achievements } \\
\text { need not be necessarily in monetary terms. }\end{array}$ & Bhalla et al., (2014) \\
\hline 2 & $\begin{array}{l}\text { Companies report more on economic dimensions rather than social and } \\
\text { environmental aspects. A study conducted on private and public } \\
\text { companies of India, shows that most companies are disclosing the three } \\
\text { sub aspects of economic performance. }\end{array}$ & \\
\hline
\end{tabular}

Table 4:- Table depicting studies related to environment dimension.

\begin{tabular}{|c|c|c|}
\hline Sl. No. & Contributions & References \\
\hline 1 & $\begin{array}{l}\text { Most MNCs report on environmental issues, focussing on water issues in } \\
\text { particular. }\end{array}$ & Tewari and Dave, (2012) \\
\hline 2 & $\begin{array}{l}\text { In India, Environmentally certified companies and larger corporations } \\
\text { follow a standard and detailed environmental reporting. }\end{array}$ & Chaklader and Gulati, (2015) \\
\hline 3 & $\begin{array}{l}\text { The firms from various sectors disclose environmental information, } \\
\text { irrespective of the environmental impact; some driving factors are global } \\
\text { competition, regulations, multinational status. A study conducted on } 50 \\
\text { Indian companies. }\end{array}$ & Chaklader et al., (2015) \\
\hline 4 & $\begin{array}{l}\text { Environmental accounting can pave way for inculcating sustainability } \\
\text { practices in the new generation industry }\end{array}$ & Burritt et al., (2016) \\
\hline
\end{tabular}




\begin{tabular}{|l|l|l|}
\hline 5 & $\begin{array}{l}\text { The increase in Sustainability Reporting and responsibility reporting has } \\
\text { led to improved efforts towards water conservation. }\end{array}$ & $\begin{array}{l}\text { Taherzadeh and West, } \\
(2016)\end{array}$ \\
\hline 6 & $\begin{array}{l}\text { Environmental Sustainability Reporting has a relationship with foreign } \\
\text { investment, board independence and size. Hence, a study of south Asian } \\
\text { countries reveal governance and environmental reporting are interlinked. }\end{array}$ & Masud et al., () \\
\hline 7 & $\begin{array}{l}\text { Environmental accounting/reporting was the first ever policy initiative } \\
\text { take by the GOI, towards sustainability i.e. EIA for 32 specified sectors. }\end{array}$ & Salgoankar, (2019) \\
\hline 8 & $\begin{array}{l}\text { A study surveying 15 years data of Indian agrochemical industries shows } \\
\text { though the reporting pattern of these companies vary they have shown a } \\
\text { greater improvement past CSR bill, 2013. Previously the CSR disclosure } \\
\text { did not contain much environmental disclosure. }\end{array}$ & $\begin{array}{l}\text { Jessop, Wilson, Bardecki } \\
\text { and Searcy, (2019) }\end{array}$ \\
\hline
\end{tabular}

Table 5:-Table showing studies on social dimension.

\begin{tabular}{|l|l|l|}
\hline Sl. No. & Contributions & References \\
\hline 1 & $\begin{array}{l}\text { CSR disclosure by top 100 IT companies of India was studied, and most } \\
\text { companies disclosed quite less information although they were engaged in } \\
\text { many social development activities. It was suggested that companies } \\
\text { should gearing (finance their websites for disclosing CSR activities. }\end{array}$ & Chaudhri and Wang, (2007) \\
\hline 2 & $\begin{array}{l}\text { A study of the top 100 Indian companies across 15 industries reveals that } \\
\text { only a quarter of companies are reporting social responsibility, but CSR } \\
\text { financial aspects are not disclosed. }\end{array}$ & $\begin{array}{l}\text { Kapoor, (2014) } \\
\text { Jose, (2013) }\end{array}$ \\
\hline 3 & $\begin{array}{l}\text { A study of 103 NSE companies proves Community related disclosures } \\
\text { have a larger impact on the profitability of the firm. }\end{array}$ & Motwani et al., (2016) \\
\hline 4 & $\begin{array}{l}\text { A sample of BSE CARBONEX indexed firms also proves CSR } \\
\text { performance has a positive impact on firm performance and this only } \\
\text { strengthens with time. }\end{array}$ & Garg (2016) \\
\hline 5 & $\begin{array}{l}\text { Voluntary guidelines for corporate social responsibilities were launched } \\
\text { in the year 2009 }\end{array}$ & Salgoankar, (2019) \\
\hline 6. & $\begin{array}{l}\text { Corporate social disclosures improve with the involvement of consultancy } \\
\text { firms and auditors, Characteristics of CEO s also impact the disclosure } \\
\text { patterns, a study of 800 firm years proves this. }\end{array}$ & $\begin{array}{l}\text { Oware and Mallikarjunappa, } \\
\text { (2020) }\end{array}$ \\
\hline
\end{tabular}

Table 6:- Table describing studies related to governance dimension.

\begin{tabular}{|l|l|l|}
\hline S1. No. & Contributions & References \\
\hline 1 & $\begin{array}{l}\text { The investigation of past literature shows that most corporates in India are } \\
\text { reporting on stakeholder engagement, with reference to GRI governance } \\
\text { guidelines which is a main part of corporate Governance. This helps in } \\
\text { balancing the conflicts amongst the stakeholders, and also helps sustain } \\
\text { the competitive environment. Sustainability Reporting has enhanced } \\
\text { governance disclosures making the corporates globally dynamic and } \\
\text { efficient. }\end{array}$ & Purohit, (2014) \\
\hline 2 & $\begin{array}{l}\text { Sustainability Reporting and mandatory CSR regulations have a } \\
\text { significant impact on governance issues in India. It has improved gender } \\
\text { parity and board composition. }\end{array}$ & Goel, (2018) \\
\hline 3 & $\begin{array}{l}\text { Indian companies are moving towards significant corporate governance, } \\
\text { with responsible and diversified boards, and new reforms. The mandatory } \\
\text { CSR spending and reporting of sustainability has created grounds for } \\
\text { better governance, but these reforms have not had a significant impact on } \\
\text { profitability. }\end{array}$ & Goel, (2019) \\
\hline 4 & $\begin{array}{l}\text { A vast literature survey of articles related to sustainability governance } \\
\text { shows that social and environmental accounting (SEA) will surely help in } \\
\text { growth and development of governance and sustainable development }\end{array}$ & Rinaldi, (2019) \\
\hline 5 & $\begin{array}{l}\text { A study of NSE top 100 companies using 52 sustainability indicators } \\
\text { reveals that governance is highly reported area. }\end{array}$ & Kumar, (2020) \\
\hline
\end{tabular}




\begin{tabular}{|l|l|l|}
\hline 6 & $\begin{array}{l}\text { The review of Corporate Governance practices in India shows CSR bill, } \\
2012 \text { and SEBI regulation have paved way for standardisation and } \\
\text { accountability and transparency among the corporates. However, the } \\
\text { Governance standards are less standardised as compared to developed } \\
\text { countries like US and UK. }\end{array}$ & Dora) \\
\hline 7 & $\begin{array}{l}\text { A robust auditing committee is best in promoting the Sustainability } \\
\text { Reporting. Independent and engaged auditing committee will help in } \\
\text { optimistic growth of quality and quantity of Sustainability Reporting and } \\
\text { helps in solving legitimacy and agency issues, }\end{array}$ & (2020) \\
\hline
\end{tabular}

\section{Findings/Discussion:-}

- Sustainability reporting draws a line of differentiation between the responsibilities of the organisation towards various stakeholders of society.

- Not only large organisations, but also small organisations can reap the benefits of the Social and environmental reporting, (Herrmen et al., 2011).

- $\quad$ There are five stages of sustainability reporting according to Landrum (2015), they are;

a) Very weak (Compliance),

b) Weak (Business centred),

c) Intermediate (Systemic),

d) Strong Sustainability (Regenerative),

e) Very Strong Sustainability (Co Evolutionary).

- Landrum and Ohsowski (2017), used these stages and identified that most organisations across the globe are still at the second stage i.e. business centric. They call for regulators and government to regularise to upraise from this phase.

- Indian firms are not disclosing all sustainability efforts. Policy makers can broaden the scope of sustainability reporting as Indian firms sustainability reporting is steered by regulations rather than stakeholders. Voluntary disclosure is most appreciated, but proper regulation and standardised practices can pave way for better sensible accountability, comparability and development, (Gray, 2001).

- Indian firms are spending money in specific sustainability dimensions not covered under ESG parameters. There seems to be a misalignment between the market expectation and Indian firm sustainability attributes, (Jha, 2020). And hence Indian firms are not receiving any financial benefits for Sustainable Investments.

- $\quad$ Financial factors are proved to be a major factor constraining sustainability reporting (Mitra et al., 2015). Lamberton, (2005) expresses concern regarding the commitment of huge resources towards sustainability reporting under the GRI framework.

- Advocacy organisations have a great impact on building CSR framework, but their engagement in CSR activities is utmost importance, it also studies the development of stake holders involvement in the accounting and reporting aspects, (Clune and O'Dwyer, 2020).

- It is found that sustainable development, Sustainability, ESG and CSR are considered almost equivalent although they have a separate theoretical background.

\section{Gaps identified in the study}

An editorial review of social and environmental accounting shows that though the social accounting/reporting is established, still there is a lot of scope for future research as many areas are to be opened up, (Laine, Scobie, Sorola and Tregidga, 2020). Some areas that are identified during our study are described as follows;

New research can be undertaken in the area of SME Sustainability reporting. As highlighted by Gibassier and Alcouffe, (2018) these organisations require a separate set of tools to measure the impact of SR or EMA on their performance, which are yet to be developed. Aparna Bhatia et al., (2014) have concluded that the reporting practices of Indian corporates are significantly optimistic but varied. Furthermore, hence suggest widening the scope and standardisation of sustainability reporting by policies and guidelines with active involvement of GOI, regulatory and professional bodies and Academic institutions. Research can be conducted to propose new models/ modules for standardisation of variables and measurement tools for sustainability reporting.

-Stephanie et al., (2019) have studied the existing literature and developed a new model of social accounting using the crowd sourced mode that is Wikirater, to link social accounting to measure the contributions of companies towards sustainable development. Also, a new accounting approach called Spotlight accounting is introduced to 
assess organisational transparency and sustainability by the independent stakeholders. This model can be tested in the Indian context.A study by Prado, et al., (2020) shows the available studies of Sustainability reporting and firm performance using the web of science and Scopus databases, it is a widely researched area, but in India only few studies are done pertaining to IT, Banking and Energy sector. Content Analysis and Cross Sector Studies about various industries can be undertaken. There is a gap of literature in studies of correlation between Sustainability Reporting and firm value, market value, stock price, profitability, etc.There is a scope of studies in the changes needed for training finance and accounting students to prepare them for future reporting of externalities i.e., sustainability reporting, (Unerman, Bebbingtonand O'dwyer, 2018). There is a wide gap in the dimension of Role of Higher Educational Institutions in Sustainability Development and Reporting. In recent years many studies are found in the developed countries in this area.An accountant should broaden his knowledge of reporting sustainability issues, (Lamberton, 2005). UNGC PRME (Principles for Responsible Management) and UNSDG 6 related to Sustainability Education. In India, there are no studies found with regard to these areas.Sustainability Reports are now a part of corporate strategies. A study of Australian and UK companies reveal a significant impact of sustainability reports on management decision making and their integration with core strategic planning, (Adams and Frost, 2008). Sustainability report and its impact on core business strategies can also be studied.

\section{Conclusion:-}

The sustainability reporting has emerged as a highly researched area in the last decade. As we step into a new decade, with new and recurring challenges, sustainability has been gaining a wider acceptance. As for Corporates, the Shareholders, Managers and Regulators and the Gatekeepers help improve the ESG disclosure in environmentally sensitive industries, (Arif et. al., 2020). However, it is evident that in India most industries are taking up SR whether environmentally sensitive or not. A robust auditing committee is best in promoting the Sustainability Reporting. Independent and engaged auditing committee will help in optimistic growth of quality and quantity of Sustainability Reporting and helps in solving legitimacy and agency issues, (Arif et al., 2020). Business communities should adhere to the needs of the stakeholders, (Ghosh, 2015). The pandemic era has produced a new dimension in CSR and its reporting, where every organisation came forward to aid the economic revival of the country, and also have been reporting for the same. This is also proved in the study conducted, by analysing the contents of Indian companies, as they are address the rising concerns of the stakeholders, (Sharma, Panday and Dangwal, 2020).

As sustainability reporting is a new approach to accounting a lot of research should the focussed on this dimension. There is a wide gap in several dimensions of Sustainability Reporting. Hence, there is a high scope for research in this area.

\section{References:-}

1. Ali, W., Frynas, J. G., \& Mahmood, Z. (2017). Determinants of Corporate Social Responsibility (CSR) Disclosure in Developed and Developing Countries: A Literature Review. Corporate Social Responsibility and Environmental Management, 24(4), 273-294. https://doi.org/10.1002/csr.1410

2. Arif, M., Sajjad, A., Farooq, S., Abrar, M., \& Joyo, A. S. (2020). The impact of audit committee attributes on the quality and quantity of environmental, social and governance (ESG) disclosures. Corporate Governance: The International Journal of Business in Society. ahead-of-p(ahead-of-print). https://doi.org/10.1108/CG-062020-0243

3. Balachandran, V., \& Saranya, S. (2014).CSR towards sustainable development under the Companies Act, 2013. International Journal of Advanced Research in Management and Social Sciences, 3(3), 28-40.

4. Bhalla, R., \& Bansal, C. S. K. (2014). Corporate sustainability reporting: a study of economic sustainability aspect by selected Indian corporations. International Journal of Current Research and Academic Review, 2(5), 37-46.

5. Bhatia, A., \& Tuli, S. (2014). Sustainable Disclosure Practices: A Study of Sensex Companies in India. Indian Journal of Corporate Governance, 7(1), 39-55.

6. Biswas, M. (2016).Corporate Sustainability Reporting in India - A Disclosure.International Journal of Management and Humanities (IJMH), 2(5), 1-8.

7. Busco, C., Sofra E. (2021). The Evolution of Sustainability Reporting: Integrated Reporting and Sustainable Development Challenges. In: Taticchi P., Demartini M. (eds) Corporate Sustainability in Practice. Management for Professionals.Springer, Cham.https://doi.org/10.1007/978-3-030-56344-8_11 
8. Campagnolo, L., Eboli, F., Farnia, L., \&Carraro, C. (2018).Supporting the UN SDG transition: Methodology for sustainability assessment and current worldwide ranking.Economics, 12(10), 1-31. https://doi.org/10.5018/economics-ejournal.ja.2018-10

9. Chaklader, B., \& Gulati, P. A. (2015). A Study of Corporate Environmental Disclosure Practices of Companies Doing Business in India. Global Business Review, 16(2), 321-335. https://doi.org/10.1177/0972150914564430

10. Charumathi, B., \& Ramesh, L. (2020). Impact of voluntary disclosure on valuation of firms: Evidence from Indian companies. Vision, 24(2), 194-203. doi:10.1177/0972262920914138

11. Chaudhri, V., \& Wang, J. (2007).Communicating corporate social responsibility on the internet: A case study of the top 100 information technology companies in India.Management Communication Quarterly, 21(2), 232247. https://doi.org/10.1177/0893318907308746

12. Clune, C., \&O’Dwyer, B. (2020).Framing Engagement that Resonates Organizing Advocacy for Corporate Social and Environmental Accountability.European Accounting Review, 29(5), 851-875. https://doi.org/10.1080/09638180.2020.1746374

13. Donaldson, T., \&Dunfee, T. (1995). Integrative Social Contracts Theory: A Communitarian Conception of Economic Ethics. Economics and Philosophy, 11(1), 85-112. doi:10.1017/S0266267100003230

14. Dora, S. Y., Bhanotu, V. R. (2020). Review of Corporate Governance Practices among USA, UK \& India : - An Analysis in Indian Context. AutAut Research Journal, 11(11), 189-206.

15. Do Prado, G. F., Piekarski, C. M., da Luz, L. M., de Souza, J. T., Salvador, R., \& de Francisco, A. C. (2020). Sustainable development and economic performance: Gaps and trends for future research. Sustainable Development, 28(1), 368-384. https://doi.org/10.1002/sd.1982

16. Du Pisani, J. A. (2006). Sustainable development - historical roots of the concept.Environmental Sciences, 3(2), 83-96. https://doi.org/10.1080/15693430600688831

17. Furlan Matos Alves, M. W., Lopes de Sousa Jabbour, A. B., Kannan, D., \&ChiappettaJabbour, C. J. (2017). Contingency theory, climate change, and low-carbon operations management.Supply Chain Management, 22(3), 223-236. https://doi.org/10.1108/SCM-09-2016-0311

18. Garg, P. (2016). CSR and corporate performance: evidence from India. Decision, 43(4), 333-349. https://doi.org/10.1007/s40622-016-0131-7

19. Garg, P. (2017). The development of sustainability reporting index (SRI) with special reference to companies in India. Decision, 44(1), 259-273 https://doi.org/10.1007/s40622-017-0162-8

20. Gibassier, D., \&Alcouffe, S. (2018). Environmental Management Accounting: The Missing Link to Sustainability? Social and Environmental Accountability Journal, 38(1), 1-18. https://doi.org/10.1080/0969160X.2018.1437057

21. Godha, A., \& Jain, P. (2015). Sustainability reporting trend in Indian companies as per GRI framework: A comparative study. South Asian Journal of Business and Management Cases, 4(1), 62-73. https://doi.org/10.1177/2277977915574040

22. Goel, P., \&Misra, R. (2017). Sustainability reporting in India: Exploring sectorial differences and linkages with financial performance. Vision, 21(2), 214-224.

23. Goel, P. (2018), "Rising standards of sustainability reporting in India: A study of impact of reforms in disclosure norms on corporate performance", Journal of Indian Business Research, Vol. ahead-of-print No. ahead-of-print. https://doi.org/10.1108/JIBR-06-2018-0166

24. Gray, R. (2001). Thirty years of social accounting, reporting and auditing: what (if anything) have we learnt? Business Ethics: A European Review, 10(1), 9-15. https://doi.org/10.1111/1467-8608.00207

25. Gray, R., Kouhy, R., \& Lavers, S. (1995). Corporate social and environmental reporting A review of the literature and a longitudinal study of UK disclosure. Accounting, Auditing \& Accountability Journal, 8(2), 4777.

26. Hahn, R., \&Kühnen, M. (2013). Determinants of sustainability reporting: a review of results, trends, theory, and opportunities in an expanding field of research. Journal of cleaner production, 59(1), 5-21.

27. Herremans, I., Pyasi, N., \& Lu, J. (2011). The journey toward sustainability reporting: How accountable are the tourism industries? Tourism Recreation Research, 36(3), 247-257.

28. Jayakumar, S., \&Suprabha, K. R. (2020). Corporate Sustainability Reporting And Firm Performance Linkage-A Literature Review Approach. PalArch's Journal of Archaeology of Egypt/Egyptology, 17(9), 7519-7527.

29. Jain, R., \& Winner, L. H. (2015). Corporate Communications : An International Journal Article information: Corporate Communication: An International Journal, 21(1), 36-55. https://doi.org/10.1108/CCIJ-02-2015-0009

30. Jessop, A., Wilson, N., Bardecki, M., \& Searcy, C. (2019). Corporate environmental disclosure in India: an analysis of multinational and domestic agrochemical corporations. Sustainability, 11(18), 4843- 4876 
31. Jha, M. K., \& Rangarajan, K. (2020).Analysis of corporate sustainability performance and corporate financial performance causal linkage in the Indian context. Asian Journal of Sustainability and Social Responsibility, 5(10), 1-30.

32. Jose, P. D., \& Saraf, S. (2013). Corporate Sustainability Initiatives Reporting: A Study of India's Most Valuable Companies. SSRN Electronic Journal, (September).https://doi.org/10.2139/ssrn.2352776

33. Jose, P. D. (Ed.). (2017). Corporations and sustainability: the South Asian perspective. Routledge.

34. Kallamu, B. S., MohdSaat, N. A., Ashikin, N., \&Saat, M. (2015). Asian Review of Accounting Article information: Asian Review of Accounting Asian Review of Accounting, 23(3), 232-255.

35. Kapoor, N. (2014). Corporate Sustainability Initiatives Reporting with reference to corporate social responsibility: A Study of selected companies. Episteme: an online interdisciplinary, multidisciplinary \& multicultural journal, 2(4), 74-93.

36. Kumar, K., \& Prakash, A. (2019). Examination of sustainability reporting practices in Indian banking sector. Asian Journal of Sustainability and Social Responsibility, 4(2), 2-16. https://doi.org/10.1186/s41180-018-00222

37. Kumar, K. (2020). Emerging phenomenon of corporate sustainability reporting: Evidence from top 100 NSE listed companies in India. Journal of Public Affairs, e2368, 1-14. https://doi.org/10.1002/pa.2368

38. Kumar, V., Gunasekaran, A., Singh, K., Papadopoulos, T., \& Dubey, R. (2015). Cross sector comparison of sustainability reports of Indian companies: A stakeholder perspective. Sustainable Production and Consumption, 4(1), 62-71.

39. Laine, M., Scobie, M., Sorola, M., \&Tregidga, H. (2020). Special Issue Editorial: Social and Environmental Account/Ability 2020 and Beyond. Social and Environmental Accountability Journal, 40(1), 1-23. https://doi.org/10.1080/0969160X.2020.1733631

40. Lamberton, G. (2005). Sustainability accounting - A brief history and conceptual framework.Accounting Forum, 29(1), 7-26.https://doi.org/10.1016/j.accfor.2004.11.001

41. Landrum, N. E., \&Ohsowski, B. (2018).Identifying Worldviews on Corporate Sustainability: A Content Analysis of Corporate Sustainability Reports.Business Strategy and the Environment, 27(1), 128-151. https://doi.org/10.1002/bse.1989

42. Leonardo, R. (2019). Accounting for Sustainability Governance: The Enabling Role of Social and Environmental Accountability Research. Social and Environmental Accountability Journal, 39(1), 1-22. DOI: 10.1080/0969160X.2019.1578675

43. Mahajan, R., \& Bose, M. (2018). Business Sustainability: Exploring the Meaning and Significance. IMI Konnect, 7(2), 8-13.

44. Mathivanan, P., \&Kasilingam, R. (2020). Regulations on sustainability reporting as a global force in shaping business enterprises: evidence from India. International Journal of Intelligent Enterprise, 7(1-3), 188-202.

45. Meuer, J., Koelbel, J., \& Hoffmann, V. H. (2020).On the nature of corporate sustainability. Organization \& Environment, 33(3), 319-341.

46. Mitra, P. K., \& Ghosh, A. (2013).An Empirical Study of Perception and Awareness about Sustainability Reporting in Indian Chemical Industry. Sumedha Journal of Management, 2(3), 38-51.

47. Mitra, P. K., Agrawal, V., \& Ghosh, A. (2015).Exploring the factors for effective sustainability reporting: A survey of Indian chemical industry. Asian Social Science, 11(3), 197-211.

48. Mitra, N. (2019). Strategic Role of Mandated Corporate Social Responsibility: The India Story. Journal of Operations and Strategic Planning, 2(2),132-162. doi:10.1177/2516600X19890709

49. Mohanty, L. (2018). Sustainability Accounting And Reporting Practices In India. Srusti Management Review, 11(1), 39-46.

50. Motwani, S. S., \& Pandya, H. B. (2016).Evaluating the impact of sustainability reporting on financial performance of selected Indian companies. International Journal of Research in IT and Management, 6(2), 1423.

51. Motwani, S. S., \& Pandya, H. B. (2016). A Study of Sustainable Disclosure Practices of Indian Corporates. IRA-International Journal of Management \& Social Sciences (ISSN 2455-2267), 4(1), 142-153. https://doi.org/10.21013/jmss.v4.n1.p13

52. Nayak, P., \&Kayarkatte, N. (2020).Sustainability Reporting in India - A Study of Infosys Sustainability Reports.International Journal of Management, Technology, and SocialSciences (IJMTS), 5(2), 336-346. DOI: http://doi.org/10.5281/zenodo.4320241

53. Omran, M. A., \& El-Galfy, A. M. (2014). Theoretical perspectives on corporate disclosure: a critical evaluation and literature survey. Asian Review of Accounting, 22 (3), 257-286. https://doi.org/10.1108/ARA-01-20140013 
54. Oware, K. M., \&Mallikarjunappa, T. (2020).Assurance service and performance.Effect of CEO characteristics.Meditari Accountancy Research, 29(1), 39-59. https://doi.org/10.1108/MEDAR-03-2020-0802

55. Oware, K. M., \&Mallikarjunappa, T. (2020). Disability employment and financial performance: the effect of technological innovation of listed firms in India. Social Responsibility Journal.https://doi.org/10.1108/SRJ-092019-0299

56. Palit, S. (2018).Emerging Significance of Sustainability Accounting and Reporting in India-A Conceptual Study. International Journal of Accounting and Financial Management Research, 8(4), 1-6.

57. Patra, S. (2016). Sustainability Reporting: A Trust towards Accountability. Amity Journal of Corporate Governance, 1(1), 34-38.

58. Perkiss, S., Dean, B., \& Gibbons, B. (2019). Crowdsourcing Corporate Transparency through Social Accounting: Conceptualising the 'Spotlight Account.' Social and Environmental Accountability Journal, 39(2), 81-99. https://doi.org/10.1080/0969160X.2019.1591292

59. Purohit, T. (2014).The Imperative Role of Corporate Governance in Building Sustainable Organizations.American International Journal of Research in Humanities, Arts and Social Sciences.,8(2), 145149.

60. Salgaonkar, V. (2019).Sustainability Reporting under Global Reporting Initiative - Performance of the Companies in India.Research Review International Journal of Multidisciplinary, 4(4), 1307-1311.

61. Scoones, I. (2007). Sustainability. Development $\quad$ in $\quad$ Practice, 17(4-5), 589 DOI: $10.1080 / 09614520701469609$

62. Sharma, P., Panday, P., \&Dangwal, R. C. (2020). Determinants of environmental, social and corporate governance (ESG) disclosure: a study of Indian companies. International Journal of Disclosure and Governance, 17(4), 208-217. https://doi.org/10.1057/s41310-020-00085-y

63. Stolowy, H., \&Paugam, L. (2018). The expansion of non-financial reporting: an exploratory study. Accounting and Business Research, 48(5), 525-548. https://doi.org/10.1080/00014788.2018.1470141

64. Taherzadeh, O. and West, C. (2016). The State of Corporate \& Government Water Reporting in India.Report for Measure What Matters project by the Stockholm Environment Institute. Available at: www.measurewhatmatters.info/resource-library/

65. Tamvada, M. (2020). Corporate social responsibility and accountability: a new theoretical foundation for regulating CSR. International Journal of Corporate Social Responsibility, 5, 1-14.

66. Tewari, R., \& Dave, D. (2012). Corporate social responsibility: Communication through sustainability reports by Indian and multinational companies. Global Business Review, 13(3), 393-405.

67. Unerman, J., Bebbington, J., \&O’dwyer, B. (2018). Corporate reporting and accounting for externalities. Accounting and Business Research, 48(5), 497-522. https://doi.org/10.1080/00014788.2018.1470155

68. Williams, O.F. (2014). The United Nations Global Compact: What Did It Promise? Journal of Business Ethics, 122(1), 241-251. https://doi.org/10.1007/s10551-014-2219-3

69. Yadava, R. N., \& Sinha, B. (2013). A Review of Corporate Sustainability Reporting: Global and National scenario. G-Journal of Environmental Science and Technology, 1(3), 76-81.

70. Yadava, R.N., Sinha, B. (2016).Scoring Sustainability Reports Using GRI 2011 Guidelines for Assessing Environmental, Economic, and Social Dimensions of Leading Public and Private Indian Companies. J Bus Ethics 138(1), 549-558. https://doi.org/10.1007/s10551-015-2597-1

71. Yadav, S., \&Budhiraj, S. (2019).CSR and Sustainability Reporting in India, the Way Forward.International Journal of Human Resource Management and Research, 9(4), 89-100. https://doi.org/10.24247/ijhrmraug20199. 